Original Article

\title{
Chemical composition and phytotoxicity of essential oils of Croton doctoris S. Moore (Euphorbiaceae)
}

\author{
Composição química e fitotoxicidade dos óleos essenciais de Croton doctoris S. Moore \\ (Euphorbiaceae)
}

\author{
A. C. S. Cândidoa* (iD) S. P. Q. Scalon ${ }^{\text {(iD , C. B. Silva }}$ (iD, E. Simionattoc (iD), A. F. Moreld (iD) , C. Z. Stüker (iD), \\ M. F. C. Matos ${ }^{\mathrm{e}}$ (iD) and M. T. L. P. Peres ${ }^{\mathrm{b}}$ (iD \\ aUniversidade Federal da Grande Dourados - UFGD, Departamento de Ciências Agrárias, Dourados, MS, Brasil \\ 'Universidade Federal de Mato Grosso do Sul - UFMS, Programa de Pós-Graduação em Biologia Vegetal, Campo Grande, MS, Brasil \\ 'Universidade Estadual de Mato Grosso do Sul - UEMS, Programa de Pós-graduação em Recursos Naturais, Naviraí, MS, Brasil \\ dUniversidade Federal de Santa Maria - UFSM, Departamento de Química, Santa Maria, RS, Brasil \\ eUniversidade Federal de Mato Grosso do Sul - UFMS, Instituto de Química, Campo Grande, MS, Brasil
}

\begin{abstract}
Essential oils from the stems and leaves of Croton doctoris were analyzed by gas chromatography and mass spectrometry, resulting in 22 identified compounds. The effects of these essential oils on the germination, root and shoot growth, total chlorophyll content, potential root respiration, peroxidase activity, catalase, superoxide dismutase, and mitotic index in lettuce and onion were determined. Antioxidant, antimicrobial, and cytotoxic activity were also investigated. The results revealed that the stem oil consisted of 15 compounds, of which caryophyllene oxide (24.5\%) and E-caryophyllene (13.3\%) were the major constituents. The leaf oil contained E-caryophyllene (39.6\%) and $\alpha$-humulene (13.2\%) as major compounds. The oils inhibited the germination and growth of lettuce and onion seedlings and reduced chlorophyll content, root respiration, and cell division. They also caused oxidative stress, indicated by the increased activity of the evaluated antioxidant enzymes. These abnormal physiological processes contributed to the inhibition of plant growth. The most pronounced phytotoxic effects were observed in the stem oil. The cytotoxicity tests indicated that leaf oil was more active than stem oil, resulting from the presence of biologically active sesquiterpenes that inhibit the growth of cancer cells.
\end{abstract}

Keywords: allelochemicals, cytotoxic activity, oxygen reactive species.

\begin{abstract}
Resumo
Os óleos essenciais do caule e da folha de Croton doctoris foram analisados por cromatografia gasosa (GC) e espectrometria de massa (GC-MS) resultando em 22 compostos identificados. Os efeitos dos óleos essenciais na germinação, crescimento de raízes e parte aérea, teor total de clorofila, respiração radicular, atividade de peroxidase, catalase e superóxido de dimetase e índice mitótico foram determinados em alface e cebola. Atividade antioxidante, antimicrobiana e citotóxica também foram investigadas. Os resultados revelaram que o óleo do caule é constituído por 15 compostos, dos quais os principais são o óxido de cariofileno (24,5\%) e E-cariofileno (13,3\%). O óleo foliar apresentou E-cariofileno (39,6\%) seguido de $\alpha$-humuleno $(13,2 \%)$ como compostos majoritários. Os óleos inibiram a germinação e o crescimento das plântulas de alface e cebola e reduziram o conteúdo de clorofila, a respiração radicular e a divisão celular. Eles também causaram estresse oxidativo, indicado pelo aumento da atividade das enzimas antioxidantes avaliadas. Esses processos fisiológicos anormais contribuem para a inibição do crescimento das plantas. Os efeitos fitotóxicos mais pronunciados foram observados no óleo do caule. Nos testes de citotoxicidade observou-se que o óleo das folhas foi mais ativo, resultante da presença de sesquiterpenos biologicamente ativos que atuam inibindo o crescimento das células cancerígenas.
\end{abstract}

Palavras-chave: aleloquímicos, atividade cititoxica, espécies reativas de oxigênio.

\section{Introduction}

The main components of essential oils (EOs) are terpenes (particularly monoterpenes and sesquiterpenes) and phenylpropanoids. These compounds exhibit broad-spectrum biological activity, serving as phytoalexins, insect repellants, pollinator attractants, and defense agents against predators, pheromones, vegetal hormones, signaling molecules and allelochemicals (Raut and Karuppayil, 2014). Essential oils are sources of natural substances with several biological activities with antioxidant, antimicrobial, anticancer, antinociceptive, antiviral, and antiphlogistic properties (Martins et al., 2015).

*e-mail: ana.candido@ufms.br

Received: December 13, 2019 - Accepted: October 5, 2020 
Essential oils have been used for centuries as flavoring agents in the manufacture of cosmetics and perfumery, and pharmacologically for medicinal purposes, which has stimulated the search for biologically active and effective substances, especially on microorganisms. Another aspect is the fact that they are natural, biodegradable, generally present low toxicity and act on several target molecules at the same time, when compared to synthetic drugs, making them key substances for the research of new drugs (Figueiredo et al., 2008). Plant materials, such as plant extracts, essential oils and pure compounds have herbicidal and antimicrobial effects against pathogens and these materials have attracted the interest of researchers around the world (Estevam et al., 2016).

The genus Croton (Euphorbiaceae) is distributed throughout all the Brazilian regions. Many Croton species are aromatic plants that produce EO, whose chemical composition and bioactivity are important aspects to investigate. Croton doctoris S. Moore (Croton: tick, seed; doctoris: doctor, medicinal) is a shrub native to deciduous forests on limestone outcrops and Chaco (Pott et al., 2007). It exhibits a branched stem, and because its leaves turn yellow-orange with age, it is locally called Amarelinho do Pantanal (wetland tiny yellow). Croton doctoris grows in dense patches in the microregion of Porto Murtinho and Corumbá in Mato Grosso do Sul (MS) state and in Paconé Pantanal (wetlands) in Mato Grosso (MT) state, representing one of the most infesting species in the area (Pott et al., 2007).

We describe the chemical composition of EO from the stem and leaves of $C$. doctoris and assess their allelopatic, antimicrobial and cytotoxic activity.

\section{Materials and Methods}

\subsection{Plant material}

The Croton doctoris samples were collected in Porto

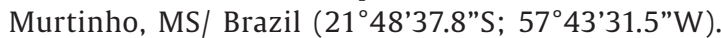
A voucher specimen was deposited in the herbarium of the Federal University of Mato Grosso do Sul (UFMS) in Campo Grande, MS/ Brazil (register number 20.164). Stems of $C$. doctoris were subjected to hydrodistillation for $4 \mathrm{~h}$ in a Clevenger device and the distillate obtained was extracted with hexane. The same procedure was repeated using fresh leaves of $C$. doctoris. Crude oil yield was calculated after solvent removal. Stem and leaf EOs were analyzed along with their phytotoxic, antimicrobial and cytotoxic effects.

\subsection{Chemical analysis}

Croton doctoris EO composition was determined by gas chromatography, using a Varian CP-3800 chromatographer equipped with a ZB-5 fused silica capillary column (5\%-phenyl-95\%-dimethylpolysiloxane) $(30 \mathrm{~m} \times 0.25 \mathrm{~mm}$, $0.2 \mathrm{~mm}$ film thickness) from Phenomenex (Torrance, CA, USA). Hydrogen was used as carrier $\left(1.0 \mathrm{~mL} \mathrm{~min}^{-1}\right)$ under the following operating conditions: split/splitless injector at $220^{\circ} \mathrm{C}$, flame ionization detector (FID) at $280^{\circ} \mathrm{C}$ and furnace temperature from $50{ }^{\circ} \mathrm{C}$ to $250{ }^{\circ} \mathrm{C}$, with $4{ }^{\circ} \mathrm{C}$ $\mathrm{min}^{-1}$ ramp rate. GC-MS analyses were performed using a Varian GC/MS/MS system, with a Varian 3900 gas chromatographer equipped with a ZB-5 capillary column, 1077 injector and CP-8410 autosampler coupled to a Varian Saturn 2100 mass spectrometer operating with $70 \mathrm{eV}$ electron impact, under the same conditions adopted in GC/ FID analysis. Oil components were identified by comparing their retention time, Kovats index and mass spectra to data from NBS/NIST library spectra and indices described by Adams (2007). A homologous series of n-alkanes $\left(C_{8}-C_{32}\right)$ was used to calculate Kovats retention indices.

\subsection{Phytotoxic activity}

We prepared $1 \%$ stock solutions of stem and leaf EOs of $C$. doctoris by diluting emulsified EO $(0.250 \mathrm{mg}$ EO in Tween 80, 1:1 v/v ratio) in distilled water. The stock solution was used to prepare EO concentrations of 0.5 , $0.25,0.12$ and $0.05 \%$. A $1 \%$ Tween 80 solution was used as control treatment.

For seed germination bioassays, $5.0 \mathrm{~mL}$ of distilled water was added to Petri dishes ( $9.0 \mathrm{~cm}$ diameter) containing filter paper (Whatman 1). Each dish was randomly sowed with 50 diaspores of lettuce (Lactuca sativa var. Grand Rapids) or onion (Allium cepa var. Baia Periforme), with four replicates per treatment (Brasil, 2009). A volume of $3.0 \mathrm{~mL}$ of each EO concentration tested was applied to two sheets of filter paper attached to a same plate cover, without direct contact with the seeds. The Petri dishes were wrapped with plastic film and taken to a germination chamber under $160 \mathrm{~W}$ light, $80 \%$ relative humidity and constant temperature, adjusted for each plant species (Brasil, 2009). After a 10-day incubation period, the germination rate was determined, the criterion of positive germination being the minimum radicle protruding $2 \mathrm{~mm}$.

To assess plant growth, 50 lettuce seeds and 50 onion seeds were germinated in Petri dishes containing filter paper moistened with $5.0 \mathrm{~mL}$ distilled water. After germination, 80 seedlings of each plant were transferred to the Petri dishes ( $N=4,20$ seedlings per plate) containing the different EO concentrations, as described for the germination assay. After 10 days of incubation, 10 seedlings were used to determine growth and dry matter, and the other 40 seedlings were used to determine chlorophyll level, root respiration, mitotic index and enzymatic activity. Seedling growth was evaluated in each dish by measuring hypocotyl and radicle elongation on a graph paper. The seedlings were then dried in a chamber forced air circulation at $65{ }^{\circ} \mathrm{C}$ to obtain dry matter.

Chlorophyll was determined from $20 \mathrm{mg}$ of lettuce and $20 \mathrm{mg}$ of onion shoot macerated in DMSO (dimethyl sulfoxide) for 24-h in the dark and at room temperature. Absorbance of the solutions containing chlorophyll was measured in spectrophotometer, at 645 and $663 \mathrm{~nm}$.

To assess potential respiration, $20 \mathrm{mg}$ of root from each plant species, cut at $1 \mathrm{~cm}$ from the cap, was placed in test tubes with $3 \mathrm{~mL}$ of $0.6 \% 2,3,5$-triphenyltetrazolium chloride (TTC) in $0.05 \mathrm{M}$ phosphate buffer $(\mathrm{pH}=7.0)$. The tubes were kept in vacuum desiccator for $2 \mathrm{~h}$ in the dark and then transferred to a water bath at $30^{\circ} \mathrm{C}$ for $15 \mathrm{~h}$. Next, the TTC 
solutions were drained, added with $7 \mathrm{~mL}$ of $95 \%$ ethanol and taken to a boiling water bath $\left(100{ }^{\circ} \mathrm{C}\right)$. After $10 \mathrm{~min}$, the ethanol solution absorbances were measured in a spectrophotometer at $530 \mathrm{~nm}$.

For mitotic index determination, $2 \mathrm{~cm}$ of the distal end of the radicles of each plant species were cut, and treated with the following sequence: distilled water for $5 \mathrm{~min}$; $1 \mathrm{M}$ chloride acid for $30 \mathrm{~min}$; distilled water for $5 \mathrm{~min}$ and $2 \%$ aceto-orcein solution for $30 \mathrm{~min}$. Radicle tips ( $2 \mathrm{~mm}$ from the cap) were cut on a slide and crushed by a cover glass. The number of cells in each mitotic phase (prophase, metaphase, anaphase and telophase) were counted under optical microscope $(1,000 \mathrm{x}$ magnification). Three slides were prepared for each treatment, and three fields were observed on each slide. The mitotic index corresponded to the quotient of the number of cells in any of the mitosis phases and the total number of cells (interphase + mitosis) multiplied by 100 .

Enzymatic activity was assessed from extracts of lettuce and onion seedlings from each treatment. The extracts were produced by macerating the seedlings in liquid nitrogen, homogenizing it with $0.2 \mathrm{M}$ potassium phosphate buffer $(\mathrm{PPB})(\mathrm{pH}=7.0)$ and centrifuging the mixture at $4000 \mathrm{rpm}$ for $20 \mathrm{~min}$. The enzymatic extract consisted of the resulting supernatant.

To assess peroxidase activity (POD), a $10 \mu \mathrm{L}$ aliquot of the extract was added to test tubes with $1 \mathrm{~mL}$ of $0.2 \mathrm{M}$ $\mathrm{PPB}(\mathrm{pH}=7.0)$ and kept in a water bath until temperature stabilization at $25{ }^{\circ} \mathrm{C}$. Immediately after adding $100 \mu \mathrm{L}$ of $0.5 \%$ guaiacol and $100 \mu \mathrm{L}$ of $0.08 \%$ hydrogen peroxide $\left(\mathrm{H}_{2} \mathrm{O}_{2}\right)$ to the tubes, the absorbance of the solution was measured in a spectrophotometer at $470 \mathrm{~nm}$, with three replicates per treatment. POD activity, calculated using the extinction coefficient of $25.5 \mathrm{mM}^{-1} \mathrm{~cm}^{-1}$, was expressed in micromoles of tetraguaiacol produced per milligram of protein.

To determine catalase activity (CAT), $100 \mu \mathrm{L}$ of the enzymatic extract was mixed with $3.0 \mathrm{~mL}$ of $12.5 \mathrm{mM} \mathrm{H}_{2} \mathrm{O}_{2}$ in $50 \mathrm{mM}$ potassium phosphate buffer $(\mathrm{pH}=7)$ at $30^{\circ} \mathrm{C}$. The absorbance of the solutions was measured at $240 \mathrm{~nm}$, with 3 replicates per treatment.

Superoxide dismutase(SOD) activity was determined from a $100 \mu \mathrm{L}$ aliquot of the extract mixed to $3.0 \mathrm{~mL}$ of a reactive medium with $0.1 \mathrm{M}$ potassium phosphate buffer $(\mathrm{pH}=7)$, $13 \mathrm{mM}$ L-methionine, $0.44 \mathrm{mM}$ nitro blue tetrazolium - NBT, $100 \mathrm{nM}$ EDTA and $1 \mathrm{mM}$ riboflavin. The solution was exposed to a $20 \mathrm{~W}$ fluorescent light for $15 \mathrm{~min}$, at $25^{\circ} \mathrm{C}$. Another extract aliquot was treated using the same protocol, but instead of being exposed to light, it was kept in the dark. SOD activity was measured by spectrophotometer at $560 \mathrm{~nm}$ for both aliquots (exposed to light or not), and the difference in absorbance represented SOD activity, expressed as units of SOD per gram of root or per milligram of protein.

Data were analyzed by analysis of variance and for significant results the means were contrasted by the Dunnet test. Statistical significance was set at an alpha error of 0.05 .

\subsection{Antimicrobial and cytotoxic activity}

The antimicrobial activity of the oils was determined by the method of minimal inhibitory concentration (MIC). The microorganism set tested included 8 species, represented by 6 bacteria (Staphylococcus aureus,
S. epidermidis, Bacillus subtilis, Escherichia coli, Pseudomonas aeruginosa and Klebsiella pneumoniae) and 2 fungi (Sacharomyces cerevisae and Candida albicans). Standard strains were obtained from the American Type Culture Collection (ATCC) and the antibiotics chloramphenicol and nystatin were used as standard. CIM was determined in 96-well plates using the microdilution method, with

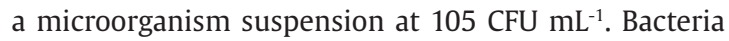
were incubated in casein soybean broth incubated for $24 \mathrm{~h}$ at $37{ }^{\circ} \mathrm{C}$ and fungi in Sabouraud broth for $72 \mathrm{~h}$ at $25^{\circ} \mathrm{C}$. Cultures that did not grow were used to inoculate solid medium plates (Muller Hinton agar and Sabouraud agar) to determine the minimal lethal concentration (MLC) of the EO dilutions, tested in triplicate according to previously described techniques (Hammer et al., 1999; NCCLS, 1995).

The cytotoxic activity was tested against 7 neoplastic cells from human tumors: MCF7 (breast cancer), NCI. ADR (adriamycin-resistant ovarian cancer), UACC.62 (melanoma), 786-0 (kidney cancer), OVCAR03 (ovarian cancer), PCO.3 (prostate cancer) and HT-29 (colon cancer). The cells were obtained from the Frederick MD National Institute of Cancer/USA. They were cultured in RPMI medium (Sigma Chemical Co., St. Louis, MO, USA) supplemented with $10 \%$ fetal bovine serum (Nutricell Nutrientes Celulares, Campinas, SP, Brazil) in humid atmosphere of $5 \% \mathrm{CO}_{2}$ at $37^{\circ} \mathrm{C}$. The medium was changed every two days until the cells reached confluency.

The cytotoxic activity of stem and leaf EOs of $C$. doctoris was evaluated by the Sulforhodamine B (SRB) method (Fátima et al., 2006). The microplates were incubated for $24 \mathrm{~h}$ at $37^{\circ} \mathrm{C}$ for stabilization and then added with $100 \mu \mathrm{L}$ of the EOs at the different concentrations $(0.25,2.5,25$ and $250 \mu \mathrm{g} \mathrm{mL}^{-1}$ ) and solubilized in DMSO and the standard compound (doxorubicin). The plates were incubated for $48 \mathrm{~h}$ at $37{ }^{\circ} \mathrm{C}$ and $5 \% \mathrm{CO}_{2}$, in triplicate. The cytotoxicity test is based on protein staining with Sulforodamine B (SRB, Sigma). This stain contains two sulfonic groups that bind to the proteins of cells fixed to the plate, making them precipitate by the action of trichloroacetic acid (TCA - Sigma). As such, after incubation the medium was replaced by $100 \mu \mathrm{L}$ of $20 \%$ TCA and the plates incubated in a refrigerator at $4{ }^{\circ} \mathrm{C}$ for $30 \mathrm{~min}$. The TCA solution was then removed and the plates washed 5 times with water. The solution was added with $50 \mu \mathrm{L}$ of $0.1 \%$ SRB (dilute in $1 \%$ acetic acid) and incubated again for $30 \mathrm{~min}$ at room temperature. After SRB removal, the plates were washed 4 times with $1 \%$ acetic acid, dried with $10 \mathrm{mM}$ Tris Base (Sigma) was added. The plates were then stirred for $10 \mathrm{~min}$ to dissolve the stained proteins, and absorbance was read at $540 \mathrm{~nm}$ in a microplate reader (Fátima et al., 2006).

\section{Results and Discussion}

\subsection{Chemical analysis}

We identified and quantified 22 compounds in both EOs of C. doctoris, 15 in stem EO and 20 in leaf EO (Table 1). The main components in stem EO were caryophyllene oxide and $E$-caryophyllene. In leaf EO, the main component was E-caryophyllene followed by $\alpha$-humulene and caryophyllene 
oxide, the three components accounting for $60.1 \%$ of total composition. In the present study, we showed that stem and leaf EOs of $C$. doctoris are composed of oxygenated and non-oxygenated sesquiterpenes and lack monoterpenes and phenylpropanoids, a composition that differs from that of other Croton species (Figure 1). These results corroborate with those found by Albuquerque et al. (2018) that verified that the essential oil of $C$. doctoris presents as sesquiterpene constituents $\beta$-caryophyllene, caryophyllene oxide and humulene.

Several studies on the chemical composition of species of the Croton genus have shown the predominance of monoterpenes and sesquiterpenes in the constitution of the essential oils of the sampled plants (Costa et al., 2013; Angélico et al., 2011). In a previous study, El Babili et al. (2009) demonstrated that caryophyllene oxide, humulene oxide and germacrene were the main components of the essential oil extracted from C. campestris dry leaves. In EO of $C$. cascarilloides leaves, the compounds identified were $\alpha$-pinene, $\beta$-caryophyllene, $\alpha$-humulene, germacrene $D$ and $\alpha$-selinene (Dai et al., 2014). Differences in the composition of essential oils can be due to several factors, including variability in the soil composition, amount and intensity of solar radiation, time of collection of the plant material, amount and type of stress received by the plant and the part of the plant used for the essential oil extraction (Dai et al., 2014; Donati et al., 2015).

\subsection{Phytotoxic activity}

In both lettuce (Figure 2) and onion (Figure 3 ), stem and leaf EOs of C. doctoris inhibited germination and reduced radicle and hypocotyl growth. The inhibitory effects were stronger using stem EO. Both EOs also decreased chlorophyll levels in lettuce and onion (Figure 4A), and this effect was proportional to the concentration. The respiratory activity of the roots or lettuce and onion (Figure 4B) also decreased in the EO treatments compared to the control. Another indicator of growth inhibition was a decrease in cell division with an increase in EO concentration

Table 1. Composition of Croton doctoris essential oil extracted from stem and leaves.

\begin{tabular}{|c|c|c|c|c|}
\hline \multicolumn{2}{|r|}{ Compound $^{\mathrm{a}}$} & \multirow{2}{*}{$\begin{array}{c}\text { Stem (\%) } \\
-\end{array}$} & \multirow{2}{*}{$\begin{array}{c}\text { Leaf (\%) } \\
0.20\end{array}$} & \multirow{2}{*}{$\begin{array}{c}\begin{array}{c}\mathbf{R I}^{\mathbf{b}} \mathbf{c} \\
\text { (GC-MS) }\end{array} \\
1375\end{array}$} \\
\hline 01 & $\alpha$-copaene & & & \\
\hline 02 & $\beta$-bourbonene & - & 0.45 & 1380 \\
\hline 03 & $\beta$-elemene & - & 1.2 & 1386 \\
\hline 04 & E-caryophyllene & 13.3 & 39.6 & 1420 \\
\hline 05 & $\beta$-copaene & - & 0.35 & 1429 \\
\hline 06 & $\alpha$-guaiene & - & 0.7 & 1434 \\
\hline 07 & aromadendrene & - & 1.2 & 1440 \\
\hline 08 & $\mathrm{Ni}$ & - & 0.4 & 1449 \\
\hline 09 & $\alpha$-humulene & 5.4 & 13.2 & 1456 \\
\hline 10 & $\beta$-selinene & 3.1 & 3.1 & 1489 \\
\hline 11 & $\alpha$-selinene & 2.7 & 3.6 & 1496 \\
\hline 12 & E-nerolidol & 5.1 & - & 1561 \\
\hline 13 & espatulenol & 5.3 & 3.4 & 1579 \\
\hline 14 & caryophyllene oxide & 24.5 & 7.5 & 1584 \\
\hline 15 & humulene epoxide II & 5.6 & 1.8 & 1612 \\
\hline 16 & $\mathrm{Ni}$ & 4.2 & 1.8 & 1618 \\
\hline 17 & alloaromadendrene epoxide & 4.2 & 1.5 & 1635 \\
\hline 18 & caryophylla-4(14), 8(15)-dien-5-ol & 5.5 & 1.5 & 1640 \\
\hline 19 & neo-intermedeol & 7.6 & 1.4 & 1660 \\
\hline 20 & $\mathrm{Ni}$ & 2.8 & - & 1667 \\
\hline 21 & 14-hydroxy-9-epi-(E)caryophyllene & 3.3 & - & 1673 \\
\hline \multirow[t]{4}{*}{22} & $\mathrm{Ni}$ & 4.2 & 4.9 & 1839 \\
\hline & Non-oxygenated sesquiterpenes & 23.9 & 64.0 & \\
\hline & Oxygenated sesquiterpenes & 61.1 & 17.1 & \\
\hline & Total & 96.8 & 87.8 & \\
\hline
\end{tabular}

aThe compounds were listed according to the sequence of elution in the chromatography column ZB-5; 'bldentification: RI, retention index, GC-MS, gas chromatography coupled to mass spectrometry; 'Index of retention under programmed-temperature conditions, determined in nonpolar column ZB-5 $\left(50-250{ }^{\circ} \mathrm{C} ; 3^{\circ} \mathrm{C} \mathrm{min}^{-1}\right)$. 


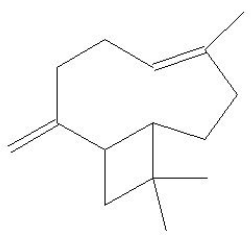

caryophyllene

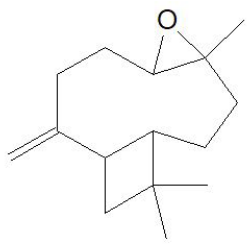

caryophyllene oxide

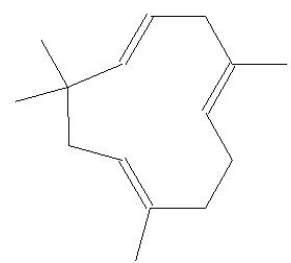

$\alpha$-humulene

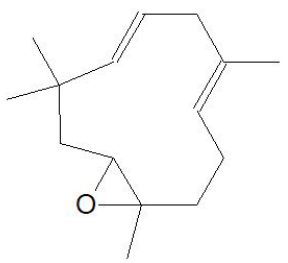

humulene epoxide

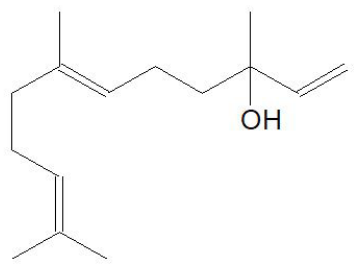

E-nerolidol

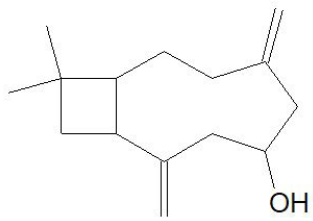

caryophylla-4(14),8(15)-dien-5-ol

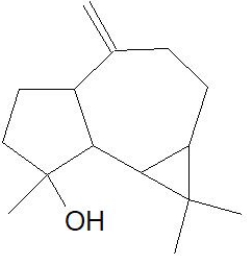

sphatulenol

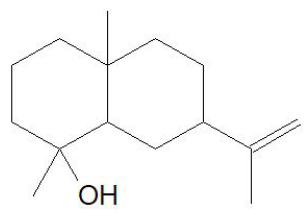

neo-intermedeol

Figure 1. Structures of the sesquiterpenes (greater than 5\%) of essential oils from leaves and and barks of Croton doctoris.

A

\section{0}
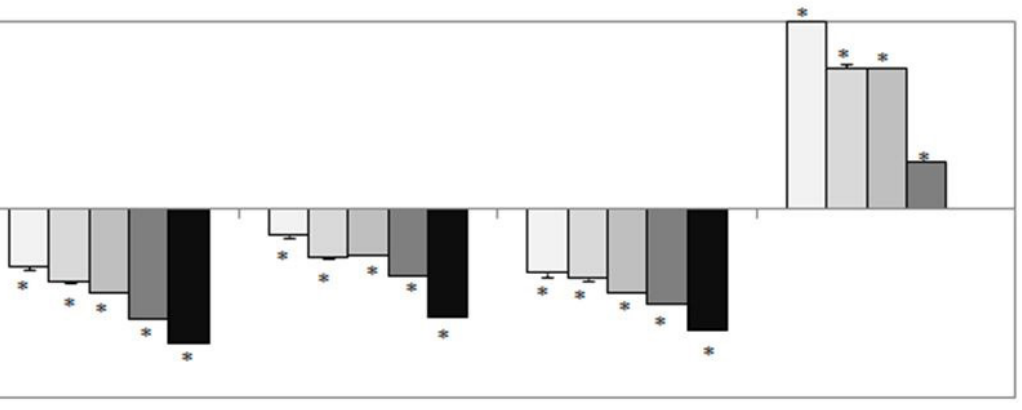

Germination Radicle Hypocotyl Dry matter

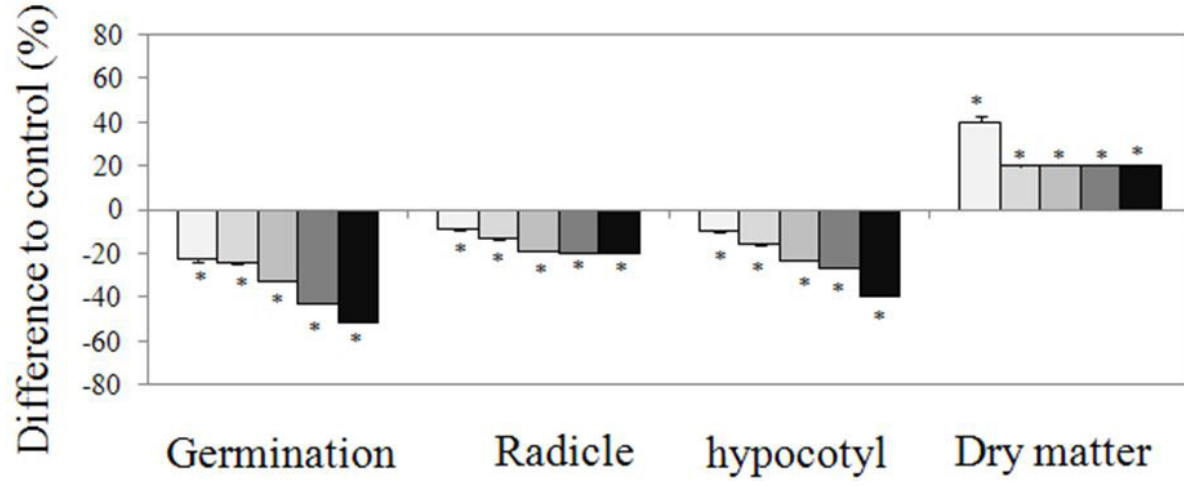

Figure 2. Effects of essential oils (EO) of stem (A) and leaves (B) of C. doctoris on germination, radicle and hypocotyl growth and dry matter of lettuce seedlings. Data are expressed as percentage difference from the control treatment. *Statistically different from the control treatment (Dunnet test, $\mathrm{p}<0.05$ ). 


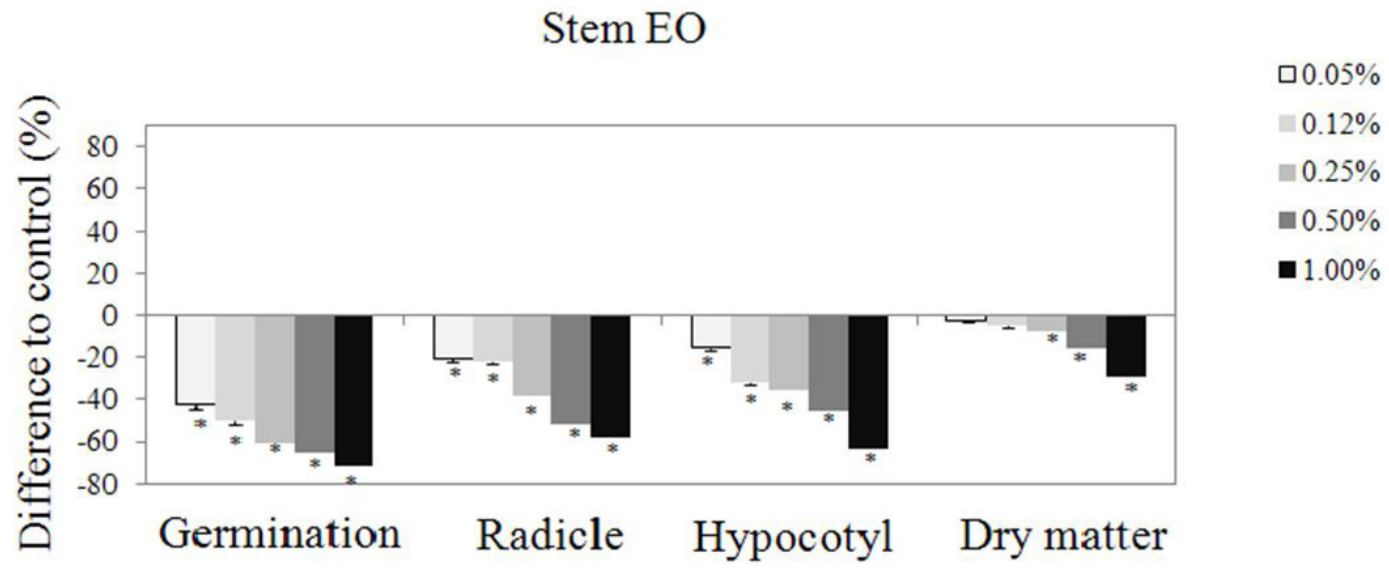

B

\section{LeafEO}

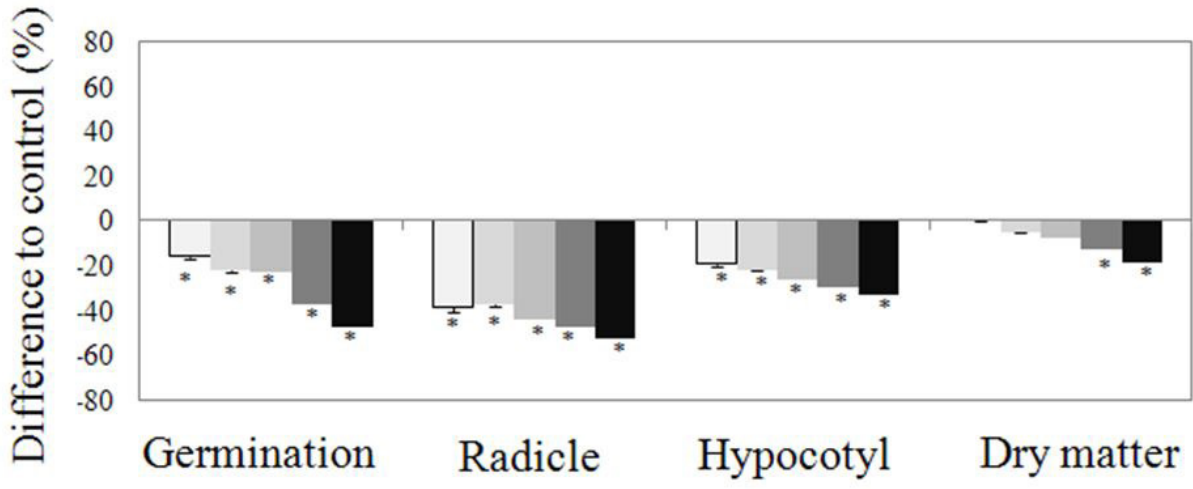

Figure 3. Effects of essential oils (EO) from stem (A) and leaves (B) of C. doctoris on germination, radicle and hypocotyl growth and dry matter of onion seedlings. Data are expressed as percentage difference from the control treatment. *Statistically different from the control treatment (Dunnet test, $\mathrm{p}<0.05$ ).

(Figure 5), except for the concentration of $0.12 \% \mathrm{EO}$ from leaves, which increased the mitotic index.

The inhibitory effect of the oils may be related to their main component, caryophyllene oxide, and the levels of oxygenated sesquiterpenes, which are higher in stem EO. Oxygenated compounds are known to be more active than their non-oxygenated counterparts. Caryophyllene is a plant compound, a member of bicyclic sesquiterpene. In nature, it mainly occurs as trans-caryophyllene mixed with small amounts of its isomers, $(Z)$ - $\beta$-caryophyllene (iso-caryophyllene) and $\alpha$-humulene ( $\alpha$-caryophyllene), as well as its oxidation derivative $\beta$-caryophyllene oxide (Fidyt et al., 2016). According this author, caryophyllene and caryophyllene oxide have strong wooden odor and they are used as cosmetic and food additives. These two natural substances are approved as flavorings by the Food and Drug Administration (FDA) and by the European Food Safety Authority (EFSA). Caryophyllene is one of the major active component of essential oils derived from large number of spice and food plants. Its biological effects these compounds include antimicrobial (Albuquerque et al., 2018), antioxidative, anti-inflammatory, anticarcinogenic (Langhasova et al., 2014), and analgesic activities
(Klauke et al., 2014). The metabolism of caryophyllene and caryophyllene oxide is poorly described (Fidyt et al., 2016).

Inhibition in seed germination and seedling growth are secondary effects of physiological processes affected by oil compounds. Other studies report that the abovementioned terpenes inhibit photosynthesis and decrease cell respiration, which was corroborated in the present study. Photosynthesis inhibition can result from chlorophyll degradation or interruption of its production, both effects mediated by allelochemicals that prevent the formation of Mg-porphyrins (Einhellig, 1986). Allelochemicals also have an impact on cell respiration at different stages and intensity, thereby affecting the parameters observed in the present study.

Cytological observations help in explaining the inhibitory effects of OEs, given that analysis of the mitotic index is an efficient method used to assess the phytotoxic effect of one plant on another (Gniazdowska and Bogatek, 2005). In fact, the most severe phytotoxic effect detected was the decreased mitotic index (Figure 5), with interruption of radicle growth (indicated by the absence of telophase), obtained with the highest concentrations of stem EO tested. Growth inhibition by interrupting cell division is likely the mechanism of action of one or more oil compounds 
A

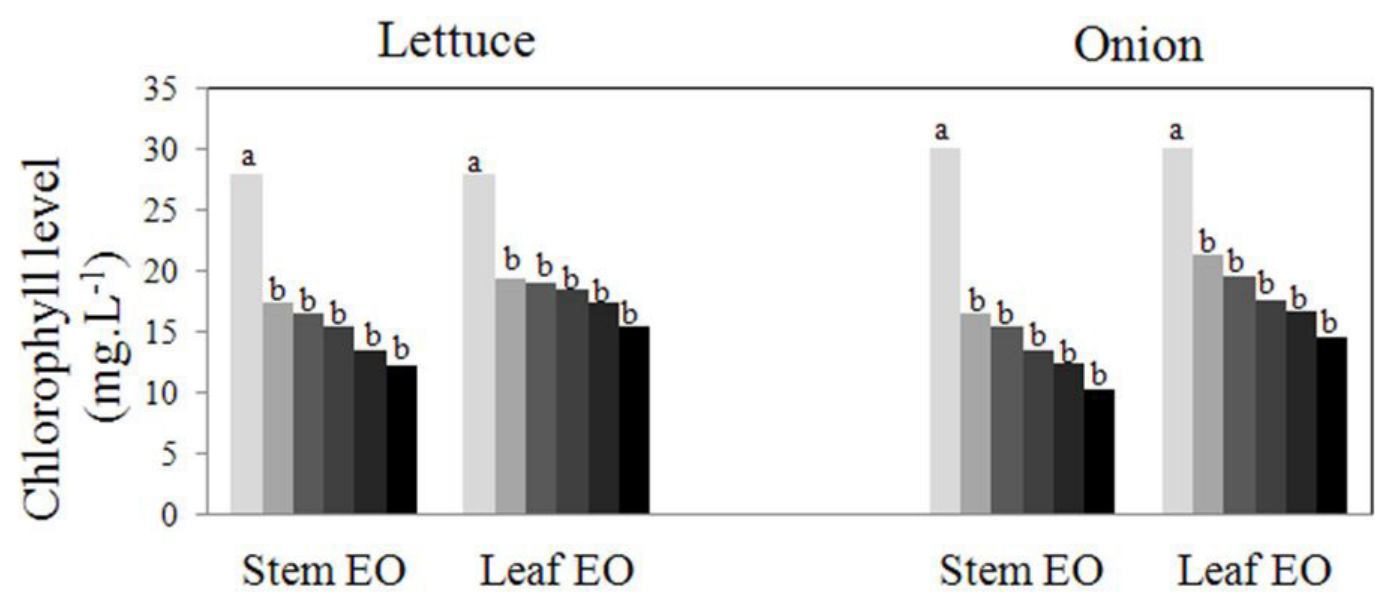

B

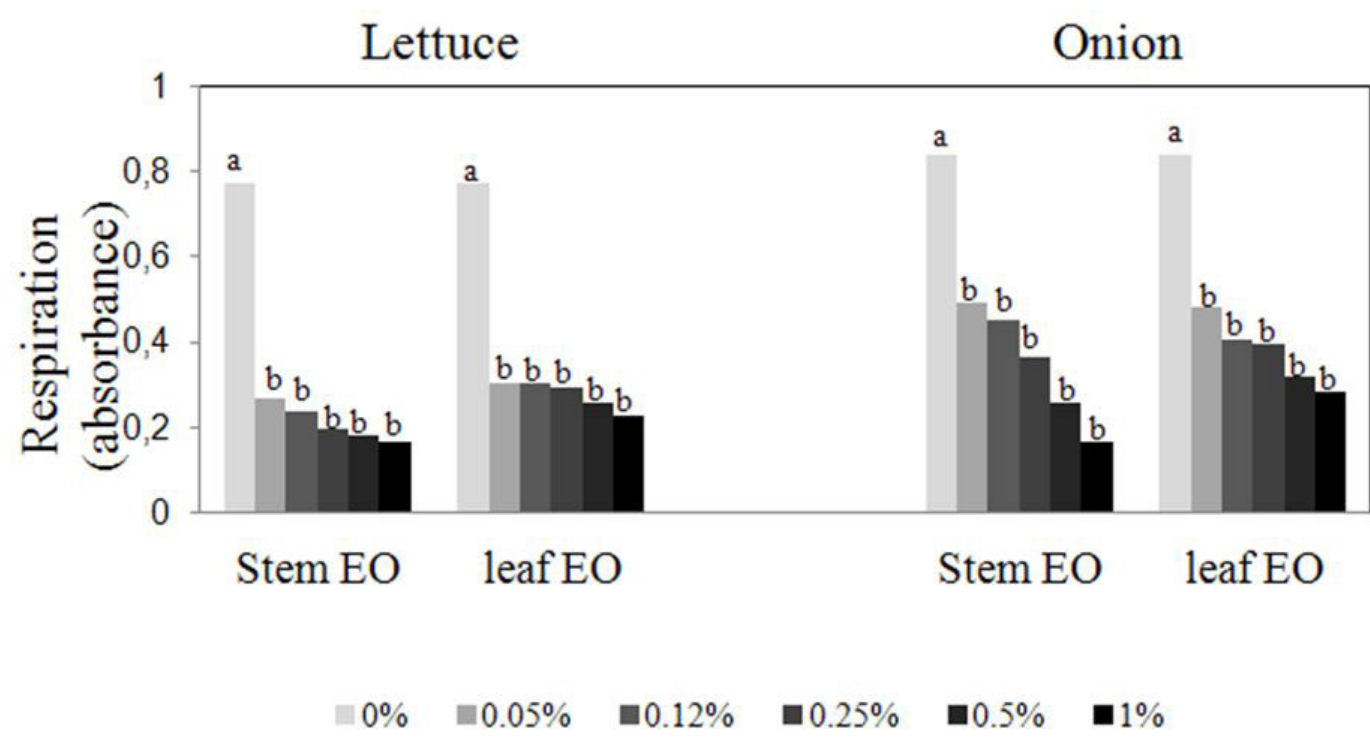

Figure 4. Effects of different concentrations of essential oils (EO) from stem and leaves of $C$. doctoris on mean chlorophyll level in the shoot (A) and potential respiration in the roots (B) (formazan produced by dehydrogenase enzymes) in lettuce and onion seedlings. Letters above the bars that are different from the letter above the control group indicate statistical difference between them (Dunnet test, $\mathrm{p}<0.05)$.

with phytotoxic activity. Cell damage is probably caused by peroxidation of lipid and protein membranes, and structures such as chloroplasts, mitochondria, nucleon and endoplasmic reticulum are destroyed because of the change in membrane permeability. The effects of abnormal physiological responses include a decrease in photosynthesis and respiration rates, contributing to a decline in plant growth, as observed in the present study. Caryophyllene and caryophyllene oxide, present in the EOs exhibit low water solubility, thereby the aqueous medium such as biological fluids, impede their absorption to the cell (Fidyt et al., 2016). However, it was shown that both compounds are able to interact with artificial lipid bilayer, which strongly suggests their high affinity to the cell membrane (Sarpietro et al., 2015). Which provides much higher bioavailability of these compounds and by that ensures obtaining observed biological effects.

Another factor to consider is the effect of EOs on oxidative stress. The EOs tested increased oxidative enzyme activity, but stem EO oil exerted the strongest effect (Figure 6). Considerable evidence indicates that allelochemicals stimulate the production of reactive oxygen species (ROS) by different mechanisms, including blocking electron transport chain production, leading to superoxide formation. For instance, the sorghum (Sorghum bicolor) component known as sorgoleone inhibits photosynthesis by blocking electron flow from photosystem II (PSII) to photosystem I (PSI) (Gniazdowska and Bogatek, 2005) due to an increase in ROS production. 

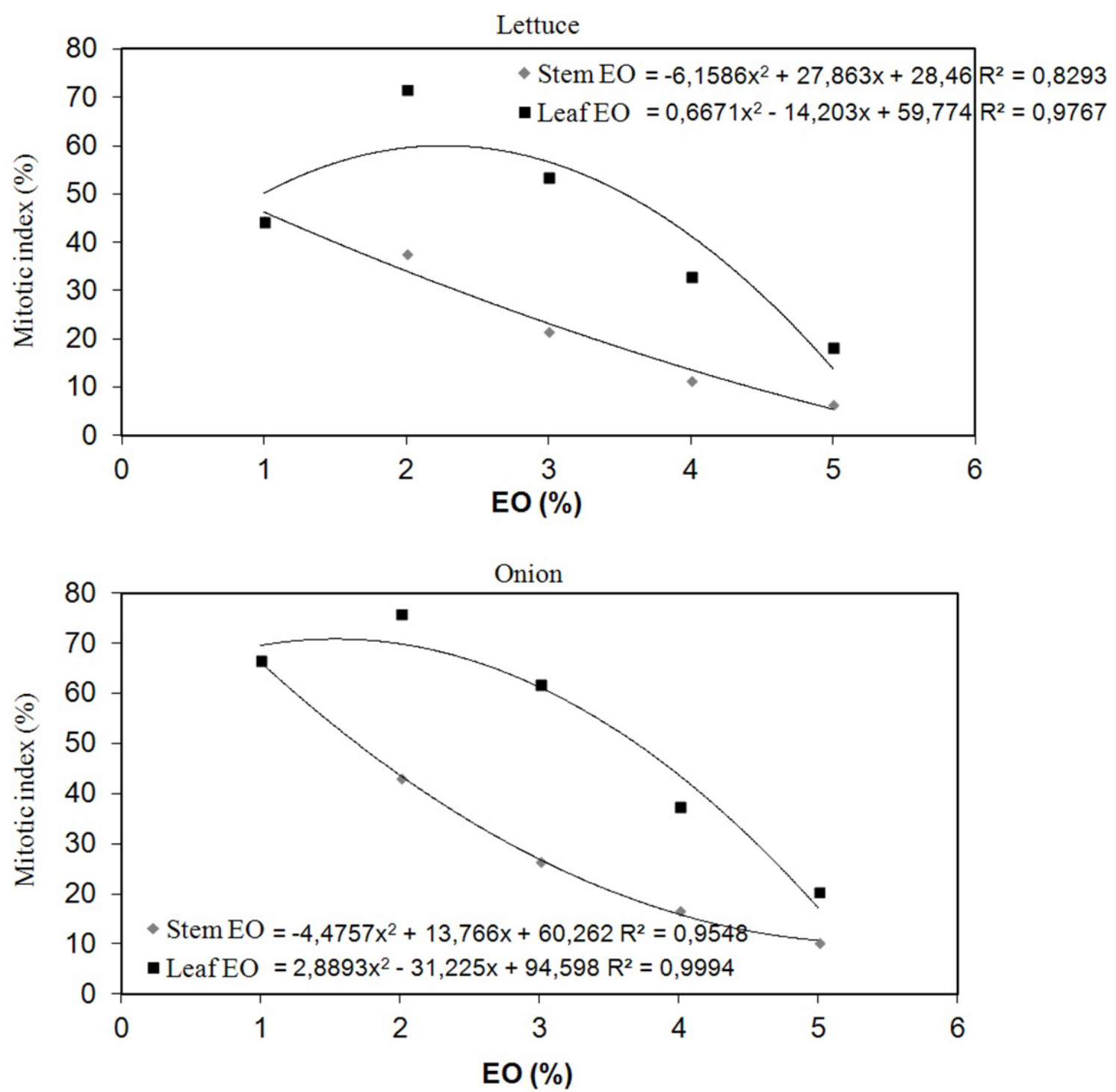

Figure 5. Effects of essential oils (EO) from stem and leaves of $C$. doctoris on the mitotic index of lettuce (A) and onion (B) seedlings.

Plants increase their enzymatic activity to combat the negative effects of ROS. The ROS increase in the present study was likely associated with a reduction in chlorophyll levels, which may have blocked the electron transport chain, thereby changing the balance of free radical production. However, although the increase in antioxidant enzyme activity levels mitigated the negative effects of free radicals, the ultimate response of the process was a decrease in seedling growth. These effects are associated to the main components present in the EO, the caryophyllene and caryophyllene oxide, which reduced the cell division of the seedlings, which resulted in reduced growth, chlorophyll content and cellular respiration. All of these processes led to changes in cellular metabolism which resulted in increased ROS.

\subsection{Antimicrobial and cytotoxic activity}

The EOs showed antimicrobial activity against the six bacteria evaluated and the fungus $C$. albicans (Table 2).
The minimum inhibitory concentration (MIC) was similar between stem and leaf EO (Table 2), reaching $10 \mathrm{mg} \mathrm{mL}^{-1}$ against $S$. aureos, S. epidermidis, B. subtilis, E. coli, P. aeruginosa and $K$. pneumoniae and $20 \mathrm{mg} \mathrm{mL}^{-1}$ against $C$. albicans. Minimal lethal concentration (MLC) was also similar between the oils, and the most sensitive microorganisms were B. subtilis, E. coli and C. albicans, with an MLC of $20 \mathrm{mg} \mathrm{mL}^{-1}$.

Several papers have reported the antimicrobial activity potential of plant essential oils against pathogens over the last decade (Sousa et al., 2015; Silva et al., 2019). Several mechanisms are proposed to explain the antimicrobial activity of essential oils. It is believed that microbial growth inhibition by essential oils is due to the direct damage to cell membrane integrity caused by their lipophilic components, which affects cell pH maintenance and inorganic ion balance. According to the literature, the inhibitory effects of essential oils are consistent with the action of monoterpene and sesquiterpene constituents on the cell membrane, and the damage to 
A

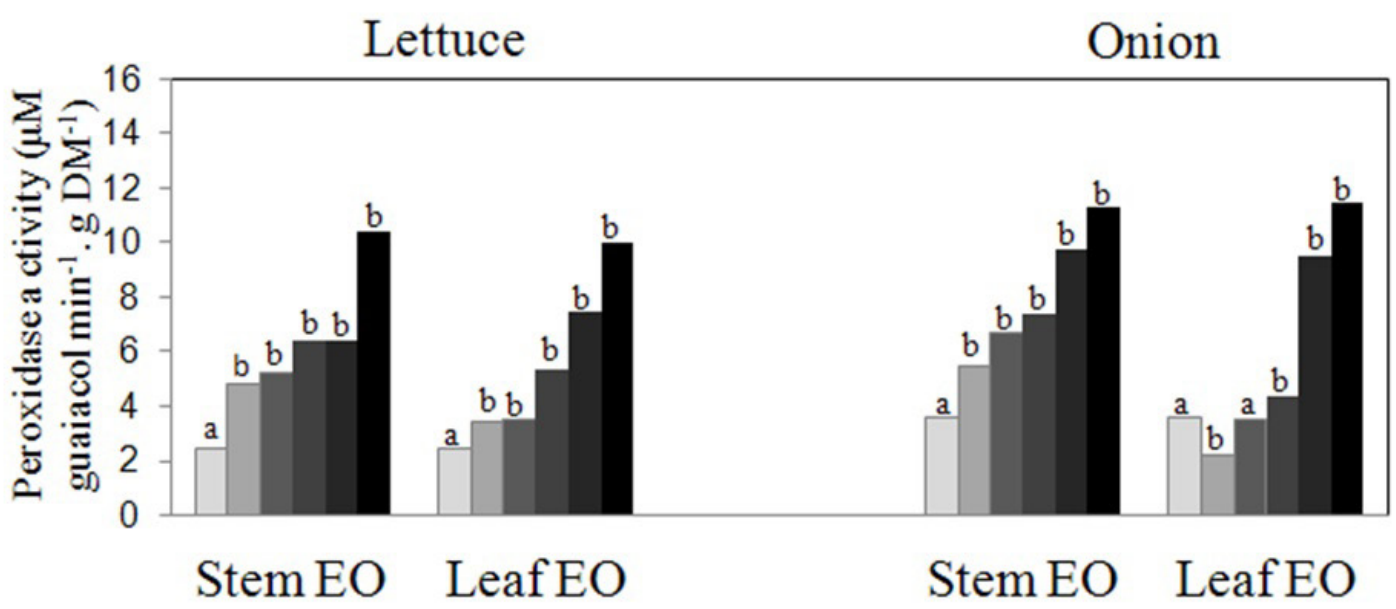

B

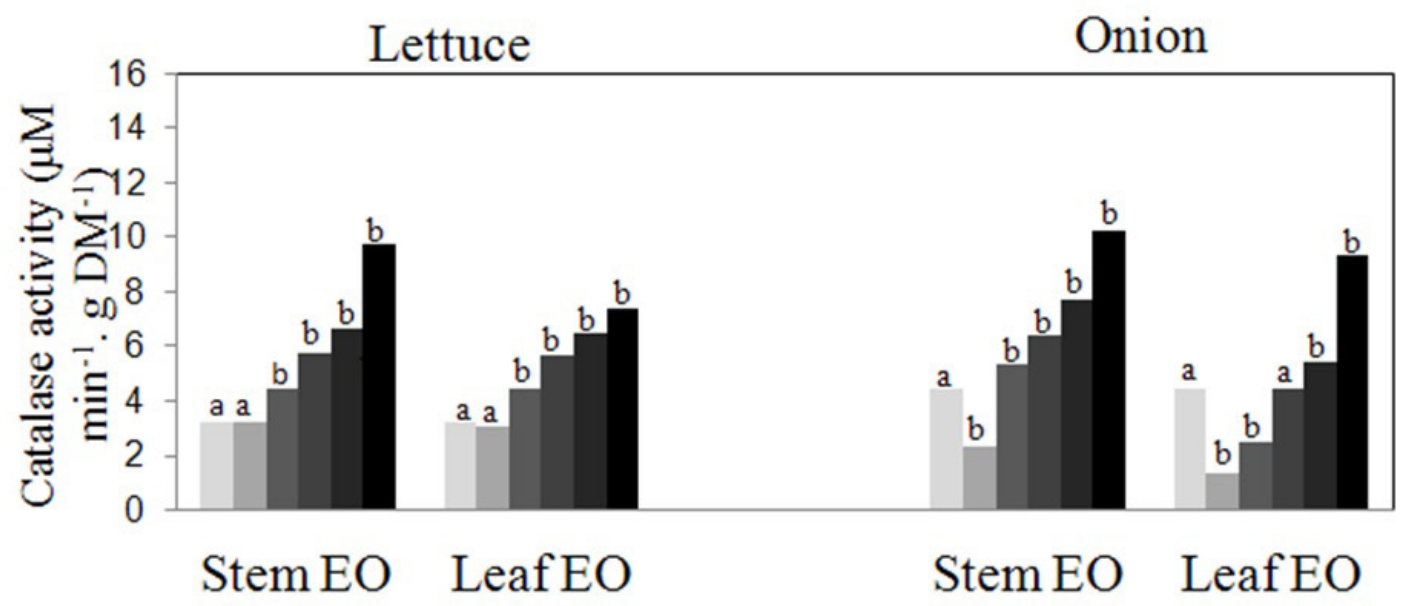

$\mathrm{C}$

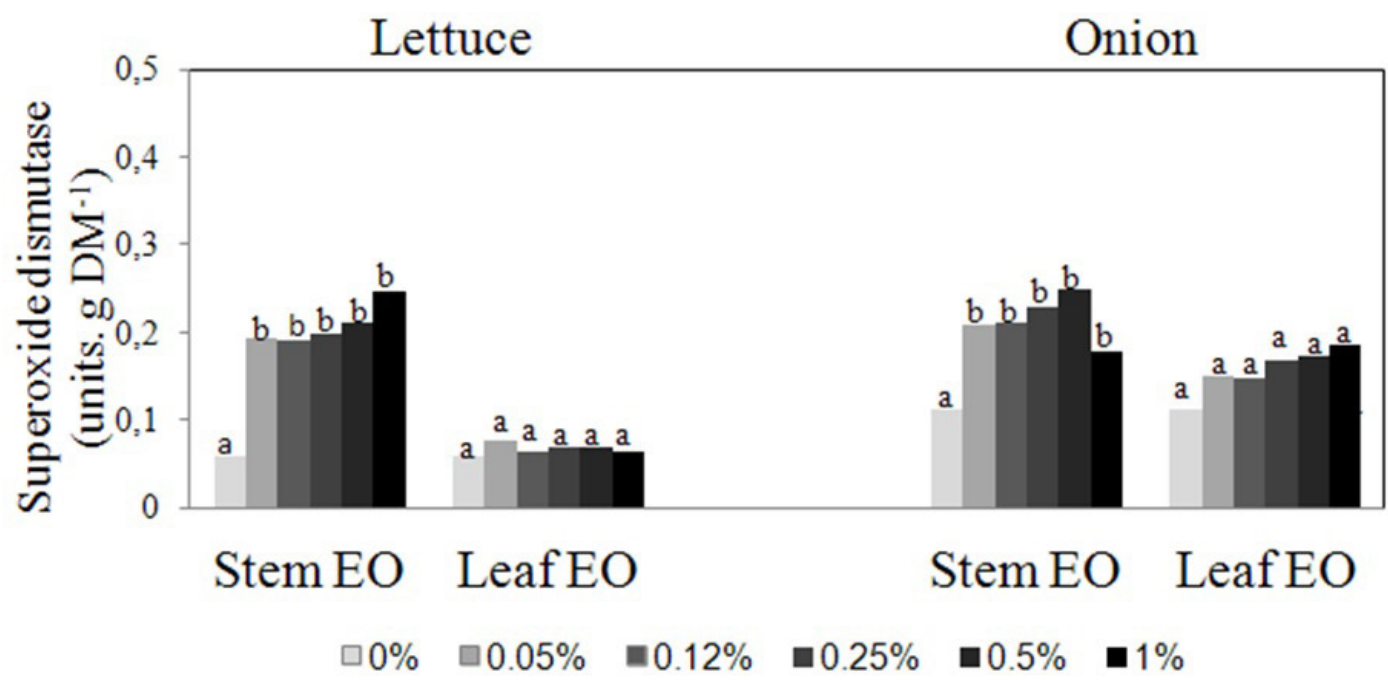

Figure 6. Effects of different concentrations of essential oils (EO) from stem and leaves of $C$. doctoris on peroxidase (A), catalase (B) and superoxide dismutase $(\mathrm{C})$ in lettuce and onion seedlings. Letters above the bars that are different from the letter above the control group indicate statistical difference between them (Dunnet test, $\mathrm{p}<0.05$ ). 
membrane produces different effects on microorganisms (Oliveira et al., 2016).

The cytotoxic activity of leaf EO against all the strains was higher than that of stem EO (Table 3). The most sensitive cells, which exhibited growth inhibition when exposed to leaf EO, were melanoma UACC62 $\left(\mathrm{IC}_{50} 13.4 \mu \mathrm{g} \mathrm{mL}{ }^{-1}\right)$ and ovarian cancer OVCAR $\left(\mathrm{IC}_{50} 21.8 \mu \mathrm{g} \mathrm{mL} \mathrm{g}^{-1}\right)$. In addition to the phytotoxic potential, the $C$. doctoris EOs also exerted bactericidal, fungicidal and cytotoxic effects. In fact, essential oils are known to be bactericidal against many bacteria species. The present study found similar bactericidal activity between stem and leaf EO, suggesting similarity between the mechanism of action of their components and the levels of these agents.

Leaf EO showed higher cytotoxic activity than stem EO, likely because it contains higher amounts of determinated sesquiterpenes such as $\alpha$-humulene, which is recognized as a potent inhibitor of neoplastic cells (Guerrini et al., 2016). Caryophyllene oxide and (E)-caryophyllene, found at significant levels in C. doctoris EO, were described as providing analgesic and anti-inflammatory action at concentrations similar to those obtained in the present study (Chavan et al., 2010). Certain EOs have great potential for inhibiting neoplastic cells (Menichini et al., 2009), and the cytotoxic activity of isolated compounds is significant. Besides, hydrocarbon monoterpenes and oxygenated monoterpenes are class of compounds that deserve special attention for its important antitumor activity (Sobral et al., 2014). The main components in EO were caryophyllene oxide and E-caryophyllene. This compounds have strong potential for being used in agricultura e medical applications, due to their phytotoxic potential and antimicrobial, antifungal and cytotoxic activity. Compounds present in EO could be applied as a bioherbicide alternative less harmful to the environment and in addition to being used in therapy for antimicrobial, antifungal and cancer treatment.

\section{Acknowledgements}

To Arnildo Pott for plant identification; to Capes, CNPq and UFMS for financial support.

\section{References}

ADAMS, R.P., 2007. Identification of essential oil components by gas chromatography/mass spectroscopy. 4th ed. Illinois: Allured Publishing Corporation, $804 \mathrm{p}$.

ALBUQUERQUE, Y.E., DANELON, M., SALVADOR, M.J., KOGA-ITO, C.Y., DELBEM, A.C.B., RAMIREZ-RUEDA, R.Y., GONTIJO, A.V.L. and BRIGHENTI, F.L., 2018. Mouthwash containing Croton doctoris essential oil: in vitro study using a validated model of caries induction. Future Microbiology, vol. 13, no. 6, pp. 631-643. http://dx.doi.org/10.2217/fmb-2017-0209. PMid:29771131.

ANGÉLICO, E.C., COSTA, J.G.M., RODRIGUES, O.G., LIMA, E.Q. and MEDEIROS, R.S., 2011. Composição química do óleo essencial das folhas de Croton blanchetianus (Baill): resultados Preliminares. Revista de Biologia e Farmácia, vol. 5, pp. 44-49.

BRASIL. Ministério da Agricultura e Reforma Agrária, 2009. Regras para a análise de sementes. Brasília: SNDA/DNDU/CLU.

Table 2. Antimicrobial activity of Croton doctoris essential oils extracted from stem and leaves.

\begin{tabular}{|c|c|c|c|c|c|}
\hline \multirow{2}{*}{ Microorganisma $^{a}$} & \multicolumn{2}{|c|}{ Stem } & \multicolumn{2}{|c|}{ Leaf } & \multirow{2}{*}{$\frac{\text { Standard }^{\mathrm{b}} \mathrm{c}}{\text { MIC }^{\mathrm{b}}}$} \\
\hline & MIC b & MLC b & MIC b & MLC b & \\
\hline Staphylococcus aureus & 10 & $>20$ & 10 & $>20$ & $3.12 \times 10^{-3}$ \\
\hline Staphylococcus epidermidis & 10 & $>20$ & 10 & $>20$ & $1.56 \times 10^{-3}$ \\
\hline Bacillus subtilis & 10 & 20 & 10 & 20 & $1.56 \times 10^{-3}$ \\
\hline Escherichia coli & 10 & 20 & 10 & 20 & $1.56 \times 10^{-3}$ \\
\hline Pseudomonas aeruginosa & 10 & $>20$ & 10 & $>20$ & $3.12 \times 10^{-3}$ \\
\hline Klebsiella pneumoniae & 10 & $>20$ & 10 & $>20$ & $3.12 \times 10^{-3}$ \\
\hline Sacharomyces cerevisae & - & - & - & - & - \\
\hline Candida albicans & 20 & 20 & 20 & $>20$ & $5.15 \times 10^{-3}$ \\
\hline
\end{tabular}

abtained from ATCC (American Type Culture Collection). The antimicrobial agents used were Chloramphenicol against bacteria and nystatin against yeast; ' Mean of 3 replicates in $\mathrm{mg} \mathrm{mL}^{-1}$; 'Standard antimicrobial agents: chloramphenicol against bacteria and nistatine against yeasts. MIC: minimum inhibitory concentration (in $\mathrm{mg} \mathrm{mL}^{-1}$ ); MLC: minimum lethal concentration (in $\mathrm{mg} \mathrm{mL}^{-1}$ ).

Table 3. Citotoxicity $\left(\mathrm{IC}_{50}\right.$ ) given in $\mu \mathrm{g} / \mathrm{mL}$, of essential oils (EO) from Croton doctoris and doxorubicin (DOX), necessary for inhibiting tumor cell proliferationa.

\begin{tabular}{lccccccc}
\hline Agent & OVCAR & MCF7 & PCO.3 & $786-0$ & UACC62 & NCIADR & HT29 \\
\hline Leaf EO & 21.8 & 61.7 & 85.8 & 32.9 & 13.4 & 43.5 & 80.3 \\
Stem EO & 74.7 & 209.4 & 94.2 & 75.0 & 56.8 & 70.9 & $>250$ \\
DOX $^{\text {b }}$ & 1.6 & 0.19 & 0.87 & 0.51 & 0.43 & 13.2 & 1.34 \\
\hline
\end{tabular}

${ }^{\mathrm{a}}$ Concentration that elicits inhibition by $50 \%$ of cell growth (IC50) was determided from non-linear regression analysis using the GraphPad Prism software; 'boxorubicin (DOX) was the positive control. OVCAR03 (ovarian cancer); MCF7 (breast cancer); PCO.3 (prostate cancer); 786 -0 (kidney cancer); UACC.62 (melanoma); NCI.ADR (adriamycin-resistant ovarian cancer); and HT-29 (colon cancer). 
CHAVAN, M.J., WAKTE, P.S. and SHINDE, D.B., 2010. Analgesic and anti-inflammatory activity of caryophyllene oxide from Annona squamosa L. bark. Phytomedicine, vol. 17, no. 2, pp. 149-151. http:// dx.doi.org/10.1016/j.phymed.2009.05.016. PMid:19576741.

COSTA, A.C.V., MELO, G.F.A., MADRUGA, M.S., COSTA, J.G.M., GARINOJUNIOR, F. and QUEIROGA NETO, V., 2013. Chemical composition and antibacterial activity of essential oil of a Croton rhamnifolioides leaves Pax \& Hoffm. Semina: Ciências Agrárias, vol. 34, no. 6, pp. 2853-2864. http://dx.doi.org/10.5433/1679-0359.2013v34n6p2853.

DAÍ, D.N., HUONG, N.L., THANG, T.D. and OGUNWANDE, I.A., 2014. Chemical constituents of essential oils of the leaves of three species of Croton from Vietnam. Chemistry of Natural Compounds, vol.50, no. 1, pp. 155-157. http://dx.doi.org/10.1007/s10600-014-0898-8.

DONATI, M., MONDIN, A., CHEN, Z., MIRANDA, F.M., NASCIMENTO JUNIOR, B.B., SCHIRATO, G., PASTORE, P. and FROLDI, G., 2015. Radical scavenging and antimicrobial activities of Croton zehntneri, Pterodon emarginatus and Schinopsis brasiliensis essential oils and their major constituents: estragole, transanethole, betacaryophyllene and myrcene. Natural Product Research, vol. 29, no. 10, pp. 939-946. http://dx.doi.org/10.10 80/14786419.2014.964709. PMid:25280163.

EINHELLIG, F.A., 1986. Mechanisms and modes of action of allelochemicals. In: A.R. PUTNAM and C.H.S. TANG, eds. The science of allelopathy. New York: John Wiley \& Sons, pp. 171-188.

EL BABILI, F., FOURASTE, I., MOULIS, C., BESSIERE, J.M., ROQUES, C. and HADDIOUI, L., 2009. Essential oil of leaves of Croton campestris St. Hilaire, Its secretory elements, and its biological activity. The Journal of Essential Oil Research, vol. 21, no. 3, pp. 272-275. http://dx.doi.org/10.1080/10412905.2009.9700168.

ESTEVAM, E.B.B., MIRANDA, M.L.D., ALVES, J.M., EGEA, M.B., PEREIRA, P.S., MARTINS, C.H.G., ESPERANDIM, V.R., MAGALHÃES, L.G., BOLELA, A.C., CAZAL, C.M., SOUZA, A.F. and ALVES, C.C.F., 2016 Composição química e atividades biológicas dos óleos essenciais das folhas frescas de Citrus limonia Osbeck e Citrus latifolia Tanaka (Rutaceae). Revista Virtual de Química, vol. 8, no. 6, pp. 1842-1854. http://dx.doi.org/10.21577/1984-6835.20160124.

FÁTIMA, A., KOHN, L.K., CARVALHO, J.E. and PILLIA, R.A., 2006. Cytotoxic activity of (S)-goniothalamin and analogues against human cancer cells. Bioorganic \& Medicinal Chemistry, vol. 14, no. 3, pp. 622-631. http://dx.doi.org/10.1016/j.bmc.2005.08.036. PMid:16202605.

FIDYT, K., FIEDOROWICZ, A., STRZADAŁA, L. and SZUMNY, A., 2016. $\beta$-caryophyllene and $\beta$-caryophyllene oxide: natural compounds of anticancer and analgesic properties. Cancer Medicine, vol.5, no. 10, pp. 3007-3017.http://dx.doi.org/10.1002/cam4.816. PMid:27696789.

FIGUEIREDO, A.C., BARROSO, J.G., PEDRO, L.G. and SCHEFFER, J.J.C., 2008. Factors affecting secondary metabolite production in plants: volatile components and essential oils. Flavour and Fragrance Journal, vol. 23, no. 4, pp. 213-226. http://dx.doi. $\operatorname{org} / 10.1002 / \mathrm{ffj} .1875$.

GNIAZDOWSKA, A. and BOGATEK, R., 2005. Phytotoxic interactions between plants. Multisite action of allelochemicals. Acta Physiologiae Plantarum, vol. 27, no. 3, pp. 395-407. http://dx.doi. org/10.1007/s11738-005-0017-3.

GUERRINI, A., SACCHETTI, G., GRANDINI, A., SPAGNOLETTI, A., ASANZA, M. and SCALVENZI, L., 2016. Cytotoxic effect and TLC bioautograph-guided approach to detect healt properties of Amazonian Hedyosmum sprucei essential oil. Evidence-Based Complementary and Alternative Medicine, vol. 2016, no. 1, pp. 1638342. PMid:27118979.

HAMMER, K.A., CARSON, C.F. and RILEY, T.V., 1999. Antimicrobial activity of essential oils and other plant extracts. Journal of Applied Microbiology, vol. 86, no. 6, pp. 985-990. http://dx.doi. org/10.1046/j.1365-2672.1999.00780.x. PMid:10438227.
KLAUKE, A.L., RACZ, I., PRADIER, B., MARKERT, A., ZIMMER, A.M., GERTSCH, J. and ZIMMER, A., 2014. The cannabinoid CB 2 receptor-selective phytocannabinoid beta-caryophyllene exerts analgesic effects in mouse models of inflammatory and neuropathic pain. European Neuropsychopharmacology, vol. 24, no. 4, pp. 608-620. http://dx.doi.org/10.1016/j. euroneuro.2013.10.008. PMid:24210682.

LANGHASOVA, L., HANUSOVA, V., REZEK, J., STOHANSLOVA, B., AMBROZ, M., KRALOVA, V., VANEK, T., LOU, J.D., YUN, Z.L., YANG, J. and SKALOVA, L., 2014. Essential oil from Myrica rubra leaves inhibits cancer cell proliferation and induces apoptosis in several human intestinal lines. Industrial Crops and Products, vol. 59, pp. 20-26. http://dx.doi.org/10.1016/j.indcrop.2014.04.018.

MARTINS, C.M., NASCIMENTO, E.A., MORAIS, S.A., OLIVEIRA, A., CHANG, R., CUNHA, L.C., MARTINS, A., MARTINS, C.H.G., MORAES, T.S., RODRIGUES, P.V., SILVA, C.V. and AQUINO, F.J., 2015. Chemical constituents and evaluation of antimicrobial and cytotoxic activities of Kielmeyera coriacea Mart. \& Zucc. Essential oils. Evidence-Based Complementary and Alternative Medicine, vol. 2015, no. 1, pp. 842047. PMid:25960759.

MENICHINI, F., CONFORTI, F., RIGANO, D., FORMISANO, C., PIOZZI, F. and SENATORE, F., 2009. Phytochemical composition, antiinflammatory and antitumour activities of four Teucrium essential oils from Greece. Food Chemistry, vol. 115, no. 2, pp. 679-686. http://dx.doi.org/10.1016/j.foodchem.2008.12.067.

NATIONAL COMMITTEE FOR CLINICAL LABORATORY STANDARDS - NCCLS, 1995. Reference method of broth dilution antifungal susceptibility testing of yeasts: Standard M77-T. Villanova: NCCLS.

OLIVEIRA, J.D., ALVES, C.C.F., MIRANDA, M.L.D., MARTINS, C.H.G., SILVA, T.S., AMBROSIO, M.A.L.V., ALVES, J.M. and SILVA, J.P., 2016. Rendimento, composição química e atividades antimicrobiana e antioxidante do óleo essencial de folhas de Campomanesia adamantium submetidas a diferentes métodos de secagem. Revista Brasileira de Plantas Medicinais, vol. 18, no. 2, pp. 502510. http://dx.doi.org/10.1590/1983-084X/15_206.

POTT, A., POTT, V.J. and SOUZA, T.W., 2007. Plantas daninhas de pastagem da região dos Cerrados. Brasília: EMBRAPA.

RAUT,J.S. and KARUPPAYIL, S.M.A., 2014. Status review on the medicinal properties of essential oils. Industrial Crops and Products, vol. 62, pp. 250-264. http://dx.doi.org/10.1016/j.indcrop.2014.05.055.

SARPIETRO, M.G.A., DI SOTTO, M.L., ACCOLLA, M.L. and CASTELLI, F., 2015. Interaction of $\beta$-caryophyllene and $\beta$-caryophyllene oxide with phospholipid bilayers: differential scanning calorimetry study. Thermochimica Acta, vol. 600, pp. 28-34. http://dx.doi. org/10.1016/j.tca.2014.11.029.

SILVA, E.A.J., ESTEVAM, E.B.B., SILVA, T.S., NICOLELLA, H.D., FURTADO, R.A., ALVES, C.C.F., SOUCHIE, E.L., MARTINS, C.H.G., TAVARES, D.C., BARBOSA, L.C.A. and MIRANDA, M.L.D., 2019. Antibacterial and antiproliferative activities of the fresh leaf essential oil of Psidium guajava L. (Myrtaceae). Brazilian Journal of Biology = Revista Brasileira de Biologia, vol. 79, no. 04, pp. 697-702. http://dx.doi.org/10.1590/1519-6984.189089. PMid:30462815.

SOBRAL, M.V., XAVIER, A.L., LIMA, T.C. and SOUSA, D.P., 2014. Antitumor activity of monoterpenes found in essential oils. The Scientific World Journal, vol. 2014, no. 1, pp. 953-451. http:// dx.doi.org/10.1155/2014/953451. PMid:25401162.

SOUSA, R.M.F., MORAIS, S.A.L., VIEIRA, R.B.K., NAPOLITANO, D.R., GUZMAN, V.B., MORAES, T.S., CUNHA, C.S., MARTINS, C.H.G., CHANG, R., AQUINO, F.J.T., NASCIMENTO, E.A. and OLIVEIRA, A., 2015. Chemical composition, cytotoxic, and antibacterial activity of the essential oil from Eugenia calycina Cambess. leaves against oral bacteria. Industrial Crops and Products, vol. 65, no. 1, pp. 71-78. http://dx.doi.org/10.1016/j.indcrop.2014.11.050. 